\title{
Periodontal phenotype modification therapy in a patient undergoing orthodontic treatment: a case report
}

Modificação de fenótipo periodontal em paciente submetido a tratamento ortodôntico: relato de caso Modificación del fenotipo periodontal en un paciente sometido a tratamiento de ortodoncia: reporte de un caso Isabelle Silvério TENÓRIO1

Maria Vitória Calado Ramalho dos SANTOS ${ }^{1}$

Ítalo de Macedo BERNARDINO ${ }^{2}$

Jamesson de Macedo ANDRADE ${ }^{2}$

Luana Samara Balduino de SENA ${ }^{2}$

Fátima Roneiva Alves FONSECA ${ }^{3}$

Rachel de Queiroz Ferreira RODRIGUES ${ }^{3}$ João Nilton Lopes de SOUSA ${ }^{3}$

${ }^{1}$ Research Assistant, Department of Dentistry, Faculty of Dentistry, Federal University of Campina Grande, Patos - Paraíba, Brazil ${ }^{2}$ Research Assistant, Department of Dentistry, State University of Paraíba, Campina Grande - Paraíba, Brazil

${ }^{3}$ Assistant Professor, Department of Dentistry, Faculty of Dentistry, Federal University of Campina Grande, Patos - Paraíba, Brazil

\begin{abstract}
Introduction: Gingival recessions are mucogingival defects of multifactorial etiology that interfere with aesthetics and function; in many cases these defects require multidisciplinary treatment. Objective: To report a clinical case of gingival recession treatment using a periodontal and orthodontic approach. Case report: Patient a 20-year-old woman, sought the Extension Project of Clinical and Surgical Periodontics (PROEPECC/UFCG) complaining of developing gingival recession in tooth 31, which was poorly positioned in the arch after orthodontic movement. Periodontal examination revealed type 1 gingival recession associated with a prominent labial frenulum, with a gingival height of $3 \mathrm{~mm}$, width of $2 \mathrm{~mm}$, probing depth of $1 \mathrm{~mm}$, and absence of attached gingiva. The root was covered using a subepithelial connective tissue graft removed from the palatal mucosa and coronally positioned flap; in addition, inferior labial frenectomy was performed. After 1 year and 6 months, tooth 31 was again moved to reposition it in the arch. One year and 10 months post-surgery, new periodontal examination was performed to evaluate the mucogingival characteristics of the treated area. The recession was completely covered and there was a 4-mm increase in the attached gingiva. Conclusion: Orthodontics may positively or negatively influence periodontal structures and periodontics may favor the prognosis of tooth movement in a risk area by modifying the periodontal phenotype, increasing its resistance to gingival recession.
\end{abstract}

Descriptors: Gingival Recession; Periodontics; Orthodontics.

\section{Resumo}

Introdução: As recessões gengivais são defeitos mucogengivais de etiologia multifatorial que interferem na estética e função; necessitando, em muitos casos, de tratamento multidisciplinar. Objetivo: Relatar um caso clínico de tratamento de recessão gengival com abordagem periodontal e ortodôntica. Relato de caso: A paciente do sexo feminino, 20 anos de idade, procurou o projeto de extensão em Periodontia Clínica e Cirúrgica - PROEPECC/UFCG, queixando-se de desenvolvimento de recessão gengival no dente 31 que se encontrava mal posicionado no arco, após movimentação ortodôntica. Ao exame periodontal, observou-se a presença de recessão gengival, do Tipo I, associada ao freio labial proeminente, com $3 \mathrm{~mm}$ de altura, $2 \mathrm{~mm}$ de largura, profundidade de sondagem de $1 \mathrm{~mm}$ e $0 \mathrm{~mm}$ de gengiva inserida. Foi realizado o recobrimento radicular com enxerto de tecido conjuntivo subepitelial removido da mucosa palatina e retalho reposicionado coronariamente, além da frenectomia labial inferior. Após 1 ano e 6 meses o dente 31 foi novamente movimentado para reposiciona-lo no arco. No pós-operatório de 1 ano e 10 meses, um novo exame periodontal foi realizado para avaliar as características mucogengivais da região tratada. A recessão foi totalmente recoberta e houve um aumento de $4 \mathrm{~mm}$ de gengiva inserida. Conclusão: A ortodontia pode influenciar de maneira positiva ou negativa nas estruturas do periodonto e a periodontia pode favorecer o prognóstico da movimentação dentária, em áreas de risco, por modificar o fenótipo periodontal, tornando-o mais resistente à recessão gengival.

Descritores: Recessão Gengival; Periodontia; Ortodontia.

\section{Resumen}

Introducción: las recesiones gingivales son defectos mucogingivales de etiología multifactorial que interfieren con la estética y la función; en muchos casos que requieren tratamiento multidisciplinario. Objetivo: informar un caso clínico de tratamiento de recesión gingival con abordaje periodontal y ortodóntico. Caso clínico: la paciente con 20 años, buscó el proyecto de extensión en Periodoncia Clínica y Quirúrgica - PROEPECC / UFCG, quejándose del desarrollo de la recesión gingival en el diente 31, que estaba mal colocado en el arco, después del movimiento de ortodoncia. En el examen periodontal, hubo presencia de recesión gingival, Tipo I, asociada con un prominente freno labial, $3 \mathrm{~mm}$ de alto, $2 \mathrm{~mm}$ de ancho, profundidad de sondeo de 1 $\mathrm{mm}$ y $0 \mathrm{~mm}$ de encía insertada. El recubrimiento de la raíz se realizó con un injerto de tejido conectivo subepitelial extraído de la mucosa palatina y un colgajo coronario reposicionado, además de la frenectomía del labio inferior. Después de 1 año y 6 meses, el diente 31 se movió nuevamente para reposicionarlo en el arco. En el postoperatorio de 1 año y 10 meses, se realizó un nuevo examen periodontal para evaluar las características mucogingivales de la región tratada. La recesión estaba completamente cubierta y hubo un aumento de $4 \mathrm{~mm}$ de encía insertada. Conclusión: la ortodoncia puede influir positiva o negativamente en las estructuras del periodonto y la periodoncia puede favorecer el pronóstico del movimiento de los dientes en áreas de riesgo, al modificar el fenotipo periodontal, haciéndolo más resistente a la recesión gingival.

Descriptores: Recesión Gingival; Periodoncia; Ortodoncia.

INTRODUCTION

According to the new Classification of Periodontal Health and Gingival Conditions and Diseases published in 2018, a patient can be diagnosed with clinical gingival health in a reduced periodontium without periodontitis when periodontal examination reveals a maximum probing depth of $3 \mathrm{~mm}$, clinical attachment loss
(CAL), and possible radiographic bone loss, but with gingival bleeding on probing at less than $10 \%$ of sites $^{1}$. These parameters are characteristic of isolated gingival recession (GR) not associated with dental biofilms ${ }^{1,2}$.

Gingival recession is defined as displacement of the gingival margin to an apical 
position in relation to the cemento-enamel junction (CEJ), with consequent exposure of the root surface ${ }^{3,4}$. In addition to aesthetic alterations, this process can cause dental hypersensitivity and cleaning problems which, in turn, predispose to the development of carious and non-carious cervical lesions and periodontal disease ${ }^{4}$.

The pathogenesis of GR is characterized by a localized inflammatory process, initiated in the epithelium of the gingival sulcus that induces it to proliferate and unite with the oral epithelium, thus reducing the amount of connective tissue in that area. With regression of the connective tissue, the marginal epithelium undergoes necrosis due to the absence of nutrition, an event that clinically manifests as a reduction of the epithelial surface ${ }^{5}$. Gingival recessions have a multifactorial etiology and can develop in patients with good or poor oral hygiene. Being determined by conditions directly linked to the development of recessions, as well as factors that predispose their occurrence ${ }^{6,7}$.

It is known that orthodontic treatment itself is not the main factor responsible for the formation of GR but its association with a series of factors can contribute to the development of this condition. Orthodontic treatment can exert a dual effect on periodontal tissues, contributing to the reestablishment of health and causing damage to the periodontium if not performed correctly. ${ }^{8}$ The treatment of GR should be based on the identification, elimination and control of the etiological factors involved in the process. Considering its multifactorial origin, the treatment of GR may require a multidisciplinary approach depending on the needs of each case $^{9,10}$.

Several mucogingival surgery techniques have been developed and improved over the years to assist in the treatment and recovery of biological patterns of periodontal tissues in cases of GR. A coronally positioned flap (CPF) in conjunction with a subepithelial connective tissue graft (SCTG) is the gold standard therapy because of its good predictability, satisfactory outcomes, and lower recurrence rates ${ }^{11}$. Therefore, a favorable prognosis can be predicted for the treatment of this mucogingival deformity when combined with periodontal therapy and individual and specific orthodontic planning. The aim of this study is to report a clinical case with a periodontal and orthodontic approach in a patient with type I gingival recession (RT1) developed after tooth movement.

\section{CLINICAL CASE}

Patient a 20-year-old brown woman without systemic alterations and with periodontal health sought the Extension Project of Clinical and Surgical Periodontics (PROEPECC), Dentistry Course, Federal University of Campina Grande, complaining of GR in tooth 31. During anamnesis performed in December 2017, the patient reported the use of an orthodontic appliance for 4 years, installed in October 2013, and the lack of any type of maintenance or follow-up by an orthodontist for one year.

Clinical and periodontal assessment revealed, in addition to GR, edge-to-edge occlusion, crowding and rotation of the affected tooth, as well as high and active muscle attachment near the gingival margin (Figure 1). The patient was submitted to periodontal examination to evaluate the probing depth, GR, and CAL of all teeth. Basic scaling and crownroot planing procedures were performed, biofilm retention factors were removed, and oral hygiene instructions were provided. Reassessment of the periodontal condition one week after initial therapy showed clinical gingival health in a reduced periodontium without periodontitis. Tooth 31 exhibited a thin periodontal phenotype, absence of gingival bleeding at all sites, and an interproximal CAL. Radiographically, the alveolar bone crest appeared close to the CEJ. Gingival recession was classified as RT1, with a height of $3 \mathrm{~mm}$, width of $2 \mathrm{~mm}$, probing depth at the buccal site of $1 \mathrm{~mm}$, absence of attached gingiva, and 1 $\mathrm{mm}$ of keratinized mucosa (Figure 2).

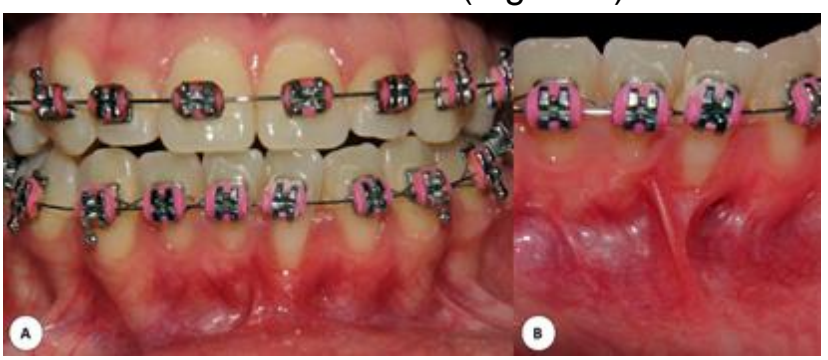

Figure 1: A, B) Clinical and periodontal appearance of the gingival recession in tooth 31 .

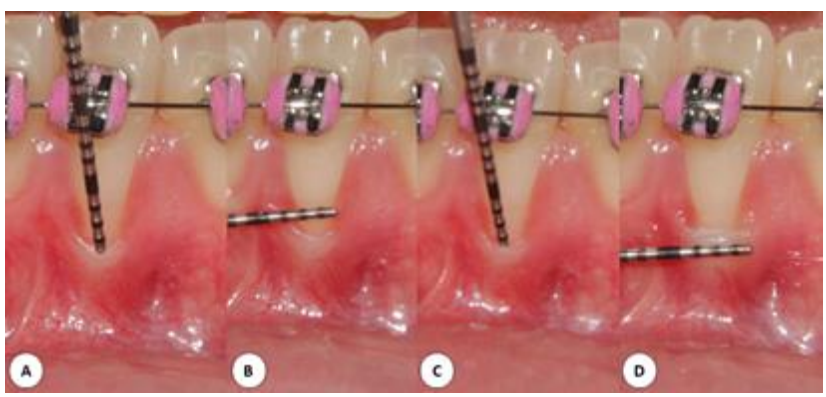

Figure 2: Assessment of gingival recession: height (A); width (B); probing depth (C), and keratinized mucosa (D).

The following etiological factors predisposing to the development of GR were observed when the orthodontic documentation obtained prior to installation of the appliance $(17 / 10 / 2013)$ and current exams (12/11/2018) to 
correct the position of the tooth were compared: thin gingiva, absence of attached gingiva, tooth malposition in the arch, frenulum and muscle insertions, and previous orthodontic movement.

Comparison of Ricketts cephalometries (Table 1) anterior and posterior to the GR revealed the occurrence of mandibular protrusion during orthodontic treatment (Figure 3). Orthodontic finishing resulted in the vestibularization of the lower incisors, with a consequent reduction in bone and periodontal support. Tooth 31 , because of its higher degree of crowding, suffered the greatest loss on the buccal surface.

Table 1. Comparison of summary diagnoses of Ricketts cephalometries anterior and posterior to the gingival recession

\begin{tabular}{l|ll} 
Parameter & \multicolumn{1}{|c}{$\begin{array}{c}\text { Ricketts cephalometry } \\
\text { Anterior }\end{array}$} & \multicolumn{1}{c}{ Posterior } \\
\cline { 2 - 3 } Molar relationship & Class I & Class I \\
\hline Canine relationship & Class I & Class I \\
\hline Convexity of point A & Concave profile & Concave profile \\
\hline $\begin{array}{l}\text { Upper incisor } \\
\text { protrusion }\end{array}$ & Upper incisor protrusion & Upper incisor protrusion \\
\hline $\begin{array}{l}\text { Lower incisor } \\
\text { protrusion }\end{array}$ & Lower incisor protrusion & Lower incisor protrusion \\
\hline Upper lip protrusion & Good position & Good position \\
\hline Facial depth & Good position & Mandibular protrusion \\
\hline Jaw depth & Good position & Good position \\
\hline $\begin{array}{l}\text { Anterior cranial base } \\
\text { length }\end{array}$ & Medium & Large \\
\hline
\end{tabular}

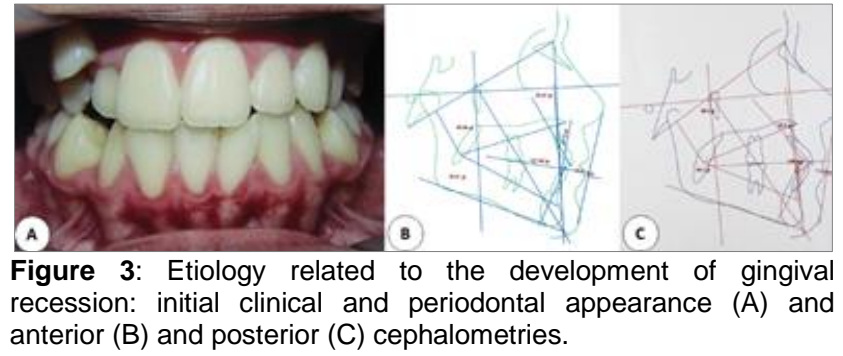

For treatment of the mucogingival deformity, temporary discontinuation of orthodontic therapy was proposed followed by periodontal phenotype modification therapy (PhMT) and coverage of the recession with an SCTG combined with CPF. In the same surgical approach, inferior labial frenectomy and subsequently PhMT, the indication of orthodontic treatment to correct the rotation and to promote bone neoformation with lingualization of the anterior lower teeth.

The patient received information about the treatment plan and about the risks and benefits of the periodontal and orthodontic procedures and agreed to participate in the study by signing the free informed consent form. The study was approved by the Ethics Committee of Faculdades Integradas de Patos (CEP/FIP) (Approval No. 59592016.8.0000.518). The technique used for root coverage is illustrated in Figure 4. Prior to preparation of the recipient site, scaling and crown-root planing were performed. Next, the root surface was treated chemically with $1 \%$ citric acid for 3 min to promote root biomodulation, followed by abundant irrigation with $0.9 \%$ saline. A flap was elevated by two horizontal incisions adjacent to the CEJ, which were joined by an intrasulcular incision. Then, the flap was moved in full thickness with a tunneling device to the mucogingival junction and, from this point, it was divided with a $15 \mathrm{C}$ scalpel blade until it reached sufficient mobility to cover the GR without muscle tension (Figure 5).

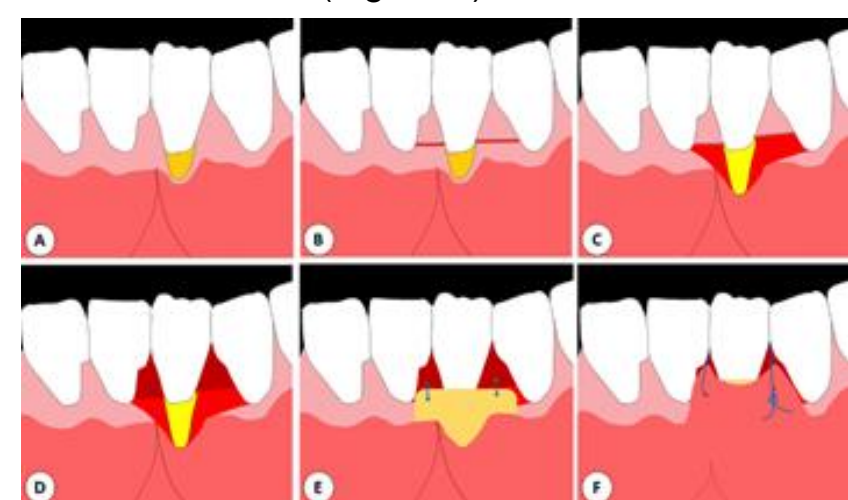

Figure 4: Illustration of the surgical technique: initial condition (A); horizontal incisions $(B)$; movement and division of the fullthickness flap (C); de-epithelization of the papillae (D); suture for graft fixation $(E)$, and suspension suture for surgical wound closure (F).

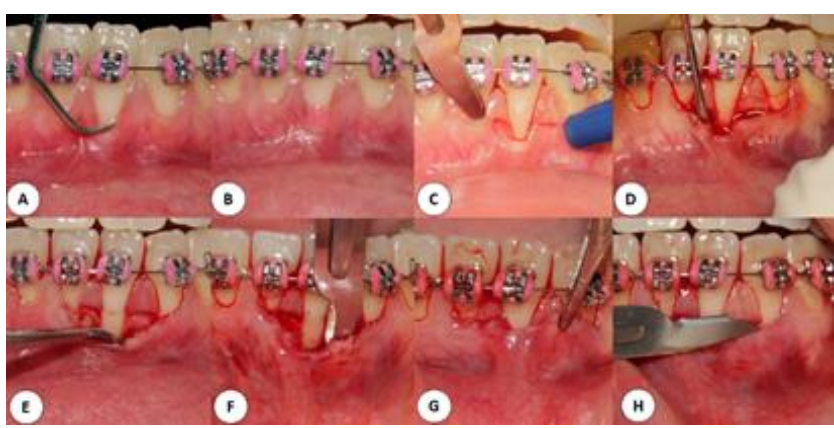

Figure 5: Preparation of the recipient site: mechanical $(A)$ and chemical $(B)$ root treatment; horizontal incisions at the height of the cemento-enamel junction $(\mathrm{C})$; fabrication of a full-thickness flap until the mucogingival junction $(D, E)$; fabrication of a partial flap $(F)$; evaluation of flap mobility $(G)$, and de-epithelization of the papillae $(\mathrm{H})$.

After preparation of the recipient site, the dimensions necessary for the graft were measured with a periodontal probe: $14 \mathrm{~mm}$ long, $6 \mathrm{~mm}$ high, and $1.5 \mathrm{~mm}$ thick. The SCTG with the cited dimensions was removed from the palatal mucosa between the distal side of the first molar and mesial side of the canine. The surgical wound was sutured with 5-0 Nylon suture by the double- $X$ technique. The graft was then adjusted and adhered adipose tissue was removed with Goldman-Fox scissors (Figure 6). The graft was sutured to the recipient site with the simple sutures at the base of the deepithelized papillae and the CPF with suspension sutures using 5-0 polyglycolic acid suture. Next, inferior labial frenectomy was performed and the wound was closed with 5-0 Nylon suture (Figure 7). 


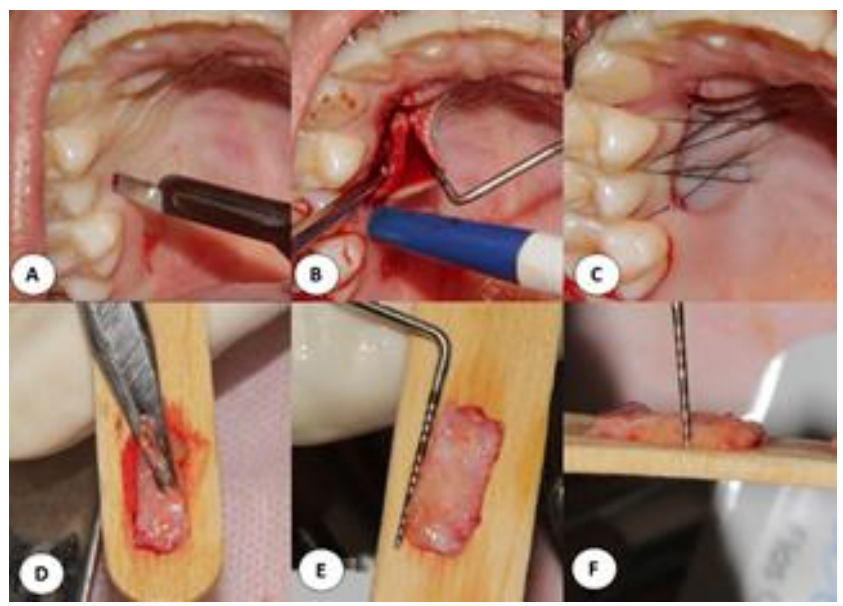

Figure 6: Removal of the subepithelial connective tissue graft by linear incision (A, B, C) and adjustment of the graft (D, E, F).

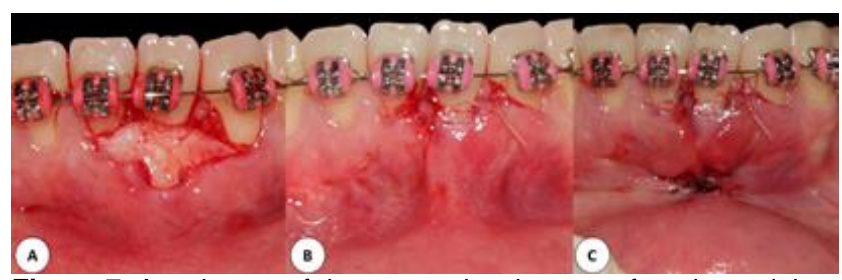

Figure 7: Attachment of the connective tissue graft to the recipient site (A); flap positioned coronally with suspension sutures (B), and inferior labial frenectomy (C).

The patient was instructed not to clean the surgical area for 14 days and received the following prescriptions: nimesulide (200 mg, once a day for 4 days), dipyrone in the case of pain $(500 \mathrm{mg}$, every $6 \mathrm{~h})$, mouth rinsing with $0.12 \%$ chlorhexidine $(15 \mathrm{ml}$, twice a day for 14 days), and a soft Curaprox toothbrush (CS 5460 Ultra Soft) for the teeth not involved in the surgical procedure, in addition to postoperative instructions. The suture was removed after 7 days and postoperative visits were scheduled at 7 days, 14 days, and 1 year (Figure 8 ).

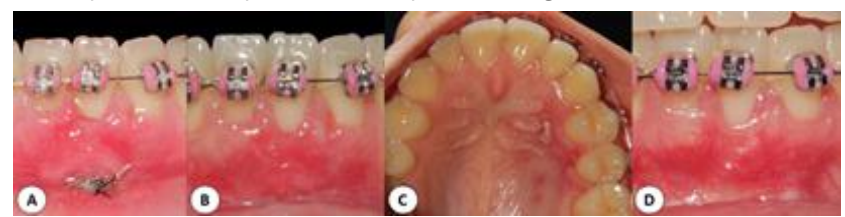

Figure 8: Follow-up of surgical treatment after 7 days (A), 14 days $(B, C)$, and 1 year (D).

One year after periodontal treatment, a new orthodontic intervention was started to correct the rotation of tooth 31 and the protrusion of the lower incisors. For this purpose, Ricketts bioprogressive philosophy was followed: 1) permitting the best torque control during retreatment, 2) performing segmented mechanics, and 3) using light forces that target only the site of the problem without affecting normal teeth and structures.

In the first session, molding was performed for fabrication of the model. Next, Bolton analysis was performed with a digital pachymeter to calculate the existing discrepancy using the overall (OT) and anterior tooth (AT) ratios. The OT was $97 \mathrm{~mm}$. OT > $91.3( \pm 1.91)$, i.e., there is an excess lower tooth mass.

$$
\begin{aligned}
& \text { OT }=\frac{12 \text { mandible }}{12 \text { maxilla }} \times 100 \quad \text { OT }=\frac{97}{100} \times 100 \quad \text { OT }=97 \\
& \quad \text { Total excess }=3.79 \mathrm{~mm}
\end{aligned}
$$

The partial ratio of six teeth, also called AT, was $82 \mathrm{~mm}$. AT > $77.2( \pm 1.65)$, i.e., there is an excess lower tooth mass.

$$
\begin{aligned}
\text { AT }= & \frac{6 \text { mandible }}{6 \text { maxilla }} \times 100 \quad \text { AT }=\frac{41}{50} \times 100 \quad \text { AT }=82 \\
& \text { Anterior excess }=3.15 \mathrm{~mm}
\end{aligned}
$$

The orthodontic brackets (Rocky Mountain $\AA$ ) were bonded to teeth 33, 32, 31, 41, 42 and 43, with anchorage on the first premolars (34 and 44) with resin in order to prevent buccal movement of the lower incisors and to avoid protrusion of the teeth involved in the movement, as well as the loss of intercanine distance, an important factor for post-orthodontic treatment stability. After bonding, interproximal reduction on the mesial and distal surfaces of teeth 42 and 32 was performed to gain space for crowding correction. DhPro® felt discs of the series recommended by the orthodontist were used for this purpose. The enamel was reduced in increments of $0.5 \mathrm{~mm}$, totaling $2 \mathrm{~mm}$ of the incisors. Next, enamel was removed from the mesial surfaces of the canines (33 and 43) in increments of $0.5 \mathrm{~mm}$, totaling $1 \mathrm{~mm}$. The total reduction obtained was $3 \mathrm{~mm}, 2 \mathrm{~mm}$ from the incisors and $1 \mathrm{~mm}$ from the canines (Figure 9).

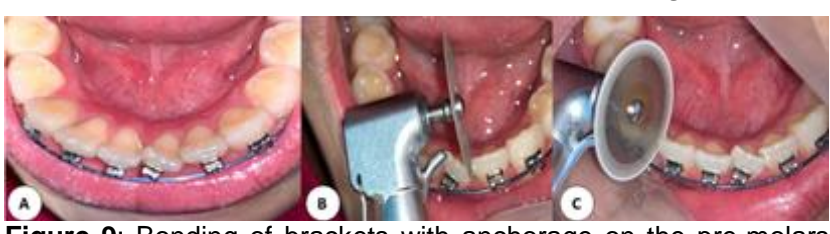

Figure 9: Bonding of brackets with anchorage on the pre-molars (A); interproximal reduction on the mesial and distal surfaces of teeth 32 and $42(B, C)$.

In the second session carried out after one month, tooth 31 was included in the mechanics with a metal ligature $(0.10 \mathrm{~mm}$ ligature wire), reducing friction during crowding correction and correcting rotation of the tooth (Figure 10a). In the third session, the brackets of teeth 31 and 41 were replaced after solving the partial crowding of tooth 31 , providing an opportunity for ideal bonding combined with the installation of a thermoactive wire $(0.14 \times 0.25)$ and closure of the diastema between teeth 33 and 34. A resin button was fabricated on tooth 44 anchored through the sectioned arch (Figure 10b).

The following sessions consisted of finishing the space closure. For this purpose, 
anchorage of teeth 33 and 34 , as well as teeth 43 and 44, was performed with ligature wire and a medium elastic rubber band was installed.

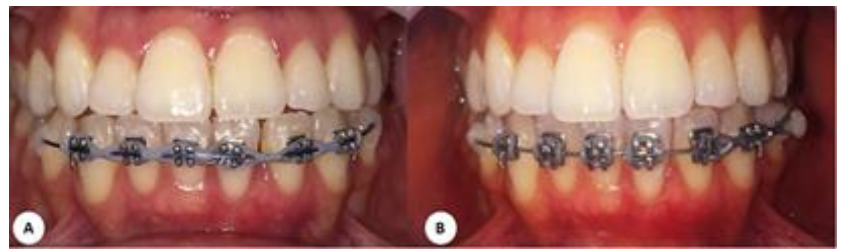

Figure 10: Metal ligature on tooth $31(\mathrm{~A})$ and resin button on teeth 34 and 44 (B)

Reassessment of the periodontal tissues in the region of tooth 31 one year and 10 months after the procedure showed stability of the root coverage and a gain of $4 \mathrm{~mm}$ in attached gingiva and keratinized mucosa (Table 2, Figure 11). In addition, periodontal plastic surgery modified the mucogingival features of the area, altering the periodontal phenotype and preventing reinsertion of the inferior labial frenulum (Figure 11). After correction of malpositioned tooth 31 , supracrestal fiberotomy was performed to stabilize the periodontal tissues and to maintain the tooth in position. The orthodontic appliance was removed after 8 days and an orthodontic retainer was installed with 0.20 stainless-steel wire (Figure 12).

Table 2. Periodontal assessment of tooth 31 before treatment and at 1 year and 10 months of follow-up.

\begin{tabular}{|c|c|c|}
\hline $\begin{array}{c}\text { Periodontal } \\
\text { parameters }\end{array}$ & Baseline & 1 year and 10 months \\
\hline Gingival recession & $3 \mathrm{~mm}$ & $0 \mathrm{~mm}$ \\
\hline Keratinized mucosa & $1 \mathrm{~mm}$ & $5 \mathrm{~mm}$ \\
\hline Probing depth & $1 \mathrm{~mm}$ & $1 \mathrm{~mm}$ \\
\hline Attached gingiva & $0 \mathrm{~mm}$ & $4 \mathrm{~mm}$ \\
\hline
\end{tabular}

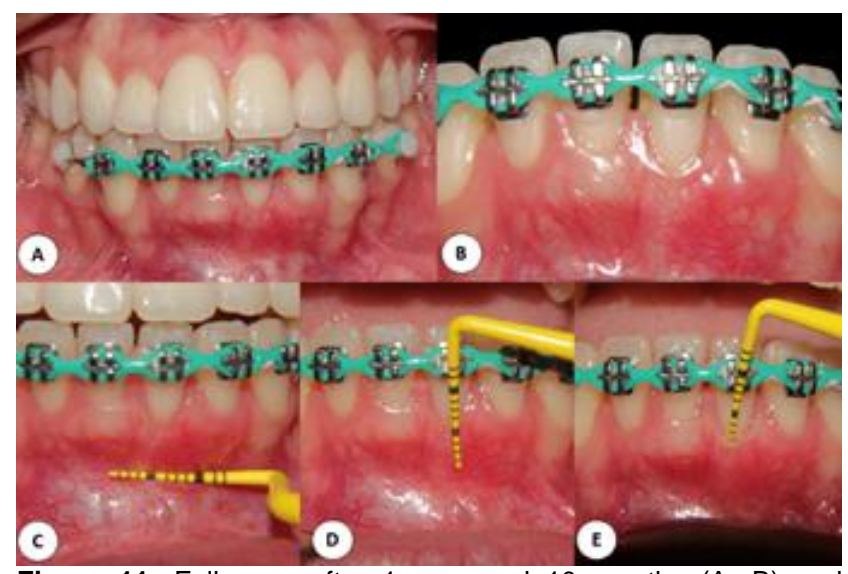

Figure 11: Follow-up after 1 year and 10 months (A, B) and assessment of the keratinized mucosa and attached gingiva created after periodontal surgery for root coverage and orthodontic movement with a ligature wire and elastic rubber bands (C, D, E).

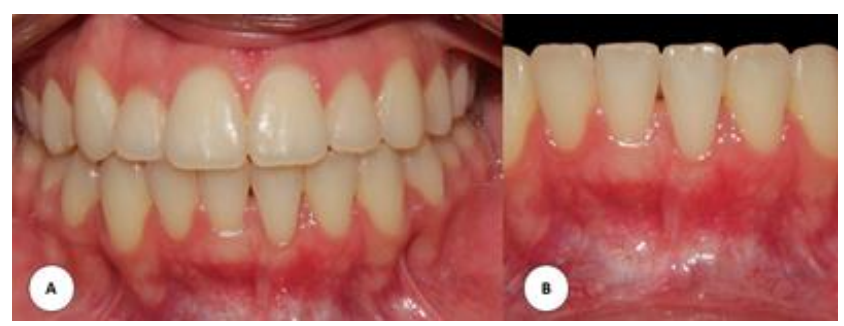

Figure 12: Final appearance after removal of the orthodontic appliance and installation of a retainer $(\mathrm{A}, \mathrm{B})$.

\section{DISCUSSION}

Gingival recession is a mucogingival alteration that is highly prevalent in clinical dental practice $^{12}$. As the gingival margin migrates apically and exposes the root surface $^{3,4}$, this condition interferes with the aesthetics and function of teeth and negatively influences the quality of life of the patient ${ }^{4,13}$.

The etiology of GR is multifactorial and some factors predispose to its development. The present patient exhibited anterior upper and lower crowding and a thin periodontal phenotype. The patient reported the occurrence of GR in tooth 31 after orthodontic movement. The latter may contribute to the development of GR in areas with these predisposing conditions ${ }^{5,12,14-16}$. In view of this diagnosis, it was necessary to combine the specialties of periodontics and orthodontics in order to correct the existing etiological factors.

Although initial orthodontic treatment had corrected the malposition of most teeth of the patient, tooth 31 continued to show rotation, edge-to-edge occlusion, and abnormal insertion of the inferior labial frenulum, which was located near the border of the recession. Root coverage was therefore preferred before the initiation of a new orthodontic approach. The recession was classified as RT1, which has an excellent prognosis as the predicted root coverage for this type is $100 \%{ }^{2,17}$.

The technique chosen for correction of the mucogingival defect was CPF combined with SCTG, which consists of collecting a connective tissue graft that is sutured to the recipient site and covered with a previously fabricated flap. This technique continues to be the gold standard therapy for root coverage because of its excellent long-term stability ${ }^{18-20}$, high predictability, and favorable aesthetcis ${ }^{21,22}$.

The connective tissue graft used here to treat GR was collected from the palatal mucosa between the mesial side of the canine and distal side of the first molar by linear incision. This approach is associated with lower morbidity and postoperative discomfort than other more invasive techniques such as the trap-door technique ${ }^{23}$. Fabricating the flap for the recipient site was a challenge because the gingival tissue was very thin and because of the presence of the active frenulum near the border of the recession, which increased the risk of flap fenestration. To reduce this risk, the flap was fabricated with a tunneling knife, which is smaller and more delicate than a Molt curette. In view of the high and active muscle attachment near the border of the tooth involved in root 
coverage, frenectomy was performed to avoid traction of the graft area and relapse of $\mathrm{GR}^{24}$.

Evaluation of the CPF technique combined with an SCTG one year and 10 months after root coverage showed an excellent outcome in terms of stability of the gingival margin, even after the second orthodontic movement. This approach provided gain in the thickness and height of the attached gingiva, demonstrating that it is an excellent technique to modify the periodontal phenotype in risk areas for the development of recession. These findings corroborate the meta-analysis of Dai et al. ${ }^{20}$ who found that this procedure provided better shortand long-term root coverage, as well as longterm gain in keratinized tissue width, when compared to CPF alone. Furthermore, Novaes and Palioto ${ }^{25}$ concluded that the CPF technique is extremely versatile and predictable for root coverage procedures, especially when combined with SCTG and/or allogenic grafts. Taken together, these findings justify the choice of the technique in the present study.

Individuals with a thin periodontal phenotype and narrow gingival width have been shown to be more susceptible to developing GR. This risk increases with orthodontic treatment and may become clinically apparent over time. ${ }^{16}$ Based on the American Academy of Periodontology consensus statement published in 2020, Kao et. ${ }^{16}$ suggested PhMT to be performed before orthodontic treatment in patients with a thin periodontal phenotype when dental movement can compromise the soft or hard tissues. The present patient had a thin periodontal phenotype and developed GR after previous orthodontic treatment, which can be attributed to the greater susceptibility of patients with this periodontal phenotype undergoing orthodontic treatment to the development of recessions. In this respect, PhMT is effective in increasing gingival width and thickness as well as keratinized tissue width, reducing periodontal complications, particularly GRs and loss of CAL, and optimizing dentoalveolar bone volume in order to prevent future recessions associated with tooth movement ${ }^{16}$.

Orthodontic treatment itself cannot be considered the cause of GR but may provide conditions that predispose to its formation, including bone dehiscences that facilitate reduction of the periodontium, especially in areas with reduced cortical bone thickness and deficient in keratinized mucosa and attached gingiva $^{5,14}$. In the present study, orthodontic intervention after root coverage contributed to the correction of malpositioned teeth and edgeto-edge occlusion, and reduced the protrusion of the lower incisors without damaging the periodontium, minimizing the risk of relapse of $\mathrm{GR}^{10}$. Orthodontic movement contributes to increase cortical thickness when positioning the involved teeth more centrally in the bone. We used anchorage with composite resin on the pre-molars for this purpose ${ }^{15}$ in order to reduce the protrusion of the lower incisors and to prevent movement to the buccal cortical bone, with consequent correction of overbite.

Ricketts bioprogressive philosophy was followed to correct crowding and rotation of the lower anterior teeth. For this purpose, segmented mechanics were used by applying light forces to move the teeth ${ }^{15}$ in order to permit continuous movement between the tooth and periodontium, predicting appositional bone growth in the thinner areas and avoiding the aggravation of attachment loss. Interproximal reduction generated space for orthodontic movement without vestibuloversion of the involved teeth ${ }^{10}$. Circumferential supracrestal fiberotomy was performed before removal of the orthodontic appliance to prevent relapse of the moved teeth after the completion of treatment, and an orthodontic retainer was subsequently installed $^{26}$.

CONCLUSION

Plastic surgery modified the mucogingival features of the area treated with an SCTG, altering the periodontal phenotype and preventing reinsertion of the inferior labial frenulum. Orthodontic treatment was fundamental by moving the tooth to a more stable position in the periodontal tissues, minimizing the risk of relapse of GR.

REFERENCES

1. Chapple ILC, Mealey BL, Van Dyke TE, Bartold $\mathrm{PM}$, Dommisch H, Eickholz $\mathrm{P}$ et al. Periodontal health and gingival diseases and conditions on an intact and a reduced periodontium: consensus report of workgroup 1 of the 2017 World Workshop on the Classification of Periodontal and Peri-Implant Diseases and Conditions. J Periodontol. 2018;89 (Suppl 1):S74-S84.

2. Steffens JP, Marcantonio RAC. Classificação das doenças e condições periodontais e periimplantares 2018: guia prático e pontoschave. Rev Odontol UNESP. 2018;47(4): 189-97.

3. Kassab MM, Cohen RE. The etiology and prevalence of gingival recession. J Am Dent Assoc. 2003;134(2):220-25.

4. Rodrigues DC, Alves R, Segundo TK. Emprego do enxerto de tecido conjuntivo subepitelial no recobrimento radicular. RGO. 2010;58(1): 115-18. 
5. Jati AS, Furquim LZ, Consolaro A. Gingival recession: its causes and types, and the importance of orthodontic treatment. Dental Press J Orthod. 2016;21(3):18-29.

6. Zucchelli G, Mounssif I. Periodontal plastic surgery. Periodontol 2000. 2015;68(1):333-68.

7. Thankkappan P, Roy S, Mandlik VB. Comparative evaluation of management of gingival recession using subepithelial connective tissue graft and collagen membrane by periodontal microsurgical technique: A clinical study of 40 cases. J Indian Soc Periodontol. 2016;20(2):189-94.

8. Rana TK, Phogat M, Sharma T, Prasad N, Singh S. Management of gingival recession associated with orthodontic treatment: a case report. J Clin Diagn Res: JCDR. 2014;8(7): ZD05-ZD07.

9. Kina JR, Suzuki TYU, Kina EFU, Kina M, Kina J. Tratamento de recessão gengival unitária. Arch. Health invest. 2015;4(6):25-30.

10. Bruscato JC, Yamamoto PS, Wuensch A, Sartorato FAS, Saba-Chujfi E. Movimento ortodôntico como auxiliar no tratamento periodontal cirúrgico: relato de caso. Braz J Periodontol. 2018;28(3):79-84.

11. Deo SD, Shetty SK, Kulloli A, Chayan R, Dholakia $P$, Ligade $S$, et al. Efficacy of free gingival graft in the treatment of Miller Class I and Class II localized gingival recessions: a systematic review. J Indian Soc Periodontol. 2010;23(2):93-9.

12. Caldato KMB, Luize DS, Nassar CA, Busato MA. Avaliação do biotipo periodontal em áreas acometidas por recessão gengival em acadêmicos de odontologia. Braz J Periodontol. 2018;28(1):19-27.

13. Wagner TP, Costa RS, Rios FS, Moura MS, Maltz M, Jardim JJ et al. Gingival recession and oral health-related quality of life: a populationbased cross-sectional study in Brazil. Community Dent Oral Epidemiol. 2016; 44(4):390-99.

14. Ribeiro LUR, Brunetto M, Medeiros CC, Derech CD, Locks A. Considerações sobre recessão gengival e sua resolução através da Ortodontia e Periodontia. Orthod Sci Pract. 2015; 8(31):415-21.

15. Gomes ZMR, Felipe LCS, Coura LR, Morais AMD, Honda R, Tiago, CM. Inter-relação ortodontia e periodontia: revisão de literatura. J Orofac Invest. 2017;4(1):30-40.

16. Kao RT, Curtis DA, Kim DM, Lin GH, Wang $\mathrm{CW}$, Cobb CM et al. American Academy of Periodontology best evidence consensus statement on modifying periodontal phenotype in preparation for orthodontic and restorative treatment. J Periodontol. 2020;91(3):289-98.

17. Cairo F, Nieri M, Cincinelli S, Mervelt J, Pagliaro $U$. The interproximal clinical attachment level to classify gingival recessions and predict root coverage outcomes: an explorative and reliability study. J Clin Periodontol. 2011;38(7):661-66.

18. Cairo F, Nieri M, Pagliaro U. Efficacy of periodontal plastic surgery procedures in the treatment of localized facial gingival recessions. A systematic review. J Clin Periodontol. 2014; 41(Suppl 15):S44-62.

19. Santos ML, Junior JKO, Costa MJF, Rodrigues RQF. Retalho reposicionado coronalmente com a finalidade de recobrimento radicular. Rev Salusvita. 2017;36(1):65-76.

20.Dai A, Huang JP, Ding PH, Chen LL. Root coverage for single gingival recessions: systematic review and meta-analysis. J Clin Periodontol. 2019;46(5):572-85.

21. Cunha FA, Hickson AES, Azevedo MYG, Cruz BCV, Cunha MAGM, Costa FO. Decisão quanto à escolha da técnica de recobrimento radicular. Perionews. 2014;8(2):142-48

22. Sena LSB, Silva NS, Andrade JM, Sousa JNL. Associação de técnicas cirúrgicas periodontais para recobrimento de recessões múltiplas e controle da dor pós operatória com laserterapia: relato de caso. Braz J Periodontol. 2017;27(4):86-90.

23. De Melo PCC, Soares LG, Falabella MEV. Recobrimento radicular com enxerto de tecido conjuntivo. PerioNews. 2015;9(1):34-41.

24. Rosa PMM, Rosa PSM, Levi YLAS, Nogueira MC, Vieira FFSL, Silveira EMV et al. Diagnóstico e tratamento cirúrgico do freio labial com inserção marginal: relato de caso. Braz J Periodontol. 2018;28(1):56-60.

25. Novaes AB Jr, Palioto DB. Experimental and clinical studies on plastic periodontal procedures. Periodontol 2000. 2019;79(1): 56-80.

26. Ishiyama M, Costa JV, Oliveira RCG. Fatores relacionados à recidiva ortodôntica. Uningá Review. 2015;24(3):72-8.

\section{CONFLICTS OF INTERESTS}

The authors declare no conflicts of interests.

CORRESPONDING AUTHOR

João Nilton Lopes de Sousa

Universidade Federal de Campina Grande

Graduação em Odontologia

Avenida Universitária, s/n - Jatobá

58708-110 Patos - PB, Brasil

Phone: (083) 3511-3000

E-mail: jnlopesodonto@gmail.com

Received 31/05/2020

Accepted 23/10/2020 